\title{
Indigenous protagonism in the context of food insecurity in times of Covid-19
}

\section{O protagonismo indígena no contexto da insegurança alimentar em tempos de Covid-19}

\section{A B S T R A C T}

In Brazil, indigenous peoples present a complex reality characterized by a marked social vulnerability that is manifested in health and nutritional indicators. In this scenario, poor sanitary conditions prevail, with a high burden of chronic noncommunicable diseases; infectious/parasitic diseases; and nutritional disorders, including malnutrition and anemia. This situation is reflected in numerous aspects of food insecurity, placing this population in a position of particular vulnerability to the coronavirus disease 2019 pandemic and its effects. The objective of our study was to present a set of preliminary reflections on food insecurity and indigenous protagonism in times of Covid-19. The pandemic has deepened the inequalities that affect the indigenous peoples, with a direct impact on food security conditions. Amid the effects of the pandemic, indigenous protagonism has played a fundamental role in guaranteeing these peoples' rights and access to food, denouncing the absent and slow official responses as acts of institutional violence, which will have serious and lasting effects on the lives of indigenous peoples.

Keywords: Coronavirus infections. Food security. Indigenous peoples. Social organization.

1 Universidade Federal de Santa Catarina, Centro de Ciências da Saúde, Departamento de Nutrição. Rua Delfino Conti, s/n., Trindade, 88040-370, Florianópolis, SC, Brasil. Correspondence to: MS LEITE. E-mail: <mauricio.leite@ufsc.br>.

2 Universidade Federal do Rio de Janeiro, Instituto de Nutrição Josué de Castro. Rio de Janeiro, RJ, Brasil.

3 Universidade Federal de Mato Grosso do Sul, Faculdade de Ciências Farmacêuticas, Alimentos e Nutrição, Curso de Nutrição. Campo Grande, MS, Brasil.

${ }^{4}$ Universidade Federal de Santa Catarina, Programa de Pós-Graduação em Nutrição, Mestrado em Nutrição. Florianópolis, SC, Brasil.

5 Universidade Federal de Roraima, Instituto Insikiran de Formação Superior Indígena. Boa Vista, RR, Brasil.

6 Fundação Oswaldo Cruz, Escola Nacional de Saúde Pública. Rio de Janeiro, RJ, Brasil.

How to cite this article

Leite MS, Ferreira AA, Bresan D, Araujo JR, Tavares IN, Santos RV. Indigenous protagonism in the context of food insecurity in times of Covid-19. Rev Nutr. 2020;33:e200171. https://doi.org/10.1590/1678-9865202033e200171 


\section{RE S U M O}

No Brasil, os povos indígenas apresentam uma realidade complexa e caracterizada por uma acentuada vulnerabilidade social, manifesta em indicadores de saúde e de nutrição. Neste cenário prevalecem condições sanitárias precárias, com elevada carga de doenças crônicas não transmissíveis, doenças infecto-parasitárias e agravos nutricionais diversos, incluindo desnutrição e anemia. Esse quadro se reflete em inúmeras faces da insegurança alimentar, situando-os em uma posição particularmente vulnerável à pandemia e seus efeitos. O objetivo deste trabalho é apresentar um conjunto de reflexões, em caráter preliminar, sobre a insegurança alimentar e o protagonismo indígena em tempos de Covid-19. A pandemia vem aprofundando as iniquidades que os atingem, com impactos diretos nas condições de segurança alimentar. O protagonismo indígena tem tido um papel fundamental na garantia de seus direitos e acesso à alimentação, denunciando a ausência e a lentidão das respostas oficiais como ações de violência institucional, que terão graves e duradouros efeitos nas trajetórias destes povos.

Palavras-chave: Infecções por coronavírus. Segurança alimentar. Povos indígenas. Organização social.

\section{INTRODUCTION}

Projections pointing toward the risk of rapid spread of coronavirus disease 2019 (Covid-19) and its devastating impacts on the indigenous people of Brazil are being confirmed every day in the ongoing course of the pandemic [1]. The epidemiological situation of the indigenous population quickly transitioned from a situation of zero cases to community transmission, with infection, mortality, and lethality rates, in some regions of the country, significantly surpassing those recorded among the nonindigenous population [2]. In the northern part of Brazil, a region with the largest number of indigenous people in the country, the mortality rate in the Distritos Sanitários Especiais Indigenas (DSEl, Special Indigenous Sanitary Districts) is estimated at 52 deaths per 100,000 people. The overall mortality in Brazil is estimated at 21 deaths per 100,000 people [1]. According to EPICOVID19-BR [3], an ongoing epidemiological survey on the situation of Covid-19 in Brazil, the self-reported indigenous individuals living in urban centers are five times more likely to have Covid-19 compared with the self-reported white population. Reporting of indigenous deaths and cases in other categories of color or race, particularly in the category "pardo" (brown), is also an issue because it leads to underreporting of indigenous cases in the statistical data [4].

In addition, the health profile of indigenous peoples in Brazil is characterized by poor sanitary conditions, with a high burden of chronic noncommunicable diseases; infectious/parasitic diseases; and nutritional disorders, including malnutrition and anemia [5]. This situation is reflected in numerous aspects of food insecurity, placing this population in a position of particular vulnerability to the pandemic and its effects. The objective of this study is to present a set of preliminary reflections on food insecurity and indigenous protagonism in times of Covid- 19.

\section{DISCUSSION}

In Brazil, indigenous peoples present a complex social diversity, comprising 305 officially recognized ethnic groups that speak 274 languages. According to the latest demographic census, 896,000 indigenous people live in urban and rural areas [6]. This segment of the population has a marked vulnerability that manifests in social and health indicators, including high prevalence of malnutrition, especially in children; anemia; and obesity [5]. The reported prevalence rates of malnutrition and anemia in indigenous children are above $50 \%$ and $80 \%$, respectively [7]. Conversely, 
the percentage of overweight individuals in this population, especially among adults, is higher than the national average, indicating an increased risk for cardiovascular disease $[8,9]$. Food acquisition profiles of indigenous people differ across the macro-regions of the country, showing that the existing regional contrasts have a direct impact on food sovereignty [10].

This scenario of vulnerabilities has been aggravated in recent years by the dismantling of public health policies for indigenous peoples. More recently, there also has been loss of social rights, directly affecting access to food and the human right to adequate food, which is guaranteed by the Federal Constitution. In this context, indigenous organizations play a key role. Even before the pandemic, these organizations were already stressing the paramount importance of protecting the rights and territories of indigenous peoples, with the aim of maintaining their lifestyles and access to food. They have been denouncing the continuous and frequent violations of their rights, including increasing invasions by land grabbers, loggers, and placer miners as well as the suspension of the processes of identification, delimitation, and demarcation of indigenous lands by the Brazilian federal government [11]. Since the publication of the "Map of Hunger among Indigenous People", the debate on food insecurity has broadened, even becoming a thematic axis in the last two national conferences on indigenous health held in Brazil [12].

In coping with the pandemic and its impacts on food insecurity, indigenous protagonism has played a fundamental role, whereas state measures have been criticized for their slow implementation and inadequacy in indigenous contexts. The insufficiency and slowness of government responses toward indigenous peoples have been denounced not only in Brazil but in other countries as well [13].

In the initial phase of the spread of the pandemic in Brazil, two major indigenous forums with Covid-19 as the central theme were held within a span of 2 weeks, and the impact of the pandemic on access to food was the topic of debate and of the demands. The "Acampamento Terra Livre 2020" (Free Land Camp 2020) was reorganized in a virtual format at the end of April 2020 [14]. In May 2020, as a response to the situation of "ineffectiveness of the public authorities in safeguarding the health of indigenous people in the midst of the pandemic", the National Assembly of Indigenous Resistance took place. Again, threats to food security and sovereignty as well as invasions of indigenous lands were denounced [15].

Throughout the last months of the spread of the pandemic, demonstrations and debates have increased both in the traditional press and social media, highlighting the intense protagonism of indigenous peoples in the most diverse issues related to Covid-19, with the worsening of food insecurity being a central issue. In this context, indigenous leaders and organizations have been working toward the preparation of a set of documents and manifests that have had important social and political repercussions and will hopefully contribute to reducing the asymmetry in the dialogues between the indigenous and nonindigenous people $[16,17]$. These manifestations have often brought to light concepts such as structural racism and genocide risk that have been increasingly leading contemporary debates on the relationship among ethnicity, indigenous peoples, and health in Brazil.

One of the first measures implemented to counter the pandemic was aimed at social distancing. For the populations in indigenous villages, the reduction in mobility between the villages and cities has the additional consequence of affecting the essential dynamics of access to food, which is already quite vulnerable. Thus, while social distancing is a fundamental measure in fighting the pandemic, in the case of indigenous populations, it cannot be dissociated from negative effects on food production, acquisition, and consumption. 
Emergency measures implemented by the federal government, such as the distribution of basic food rations and an emergency aid of $\mathrm{R} \$ 600.00$ (Brazilian reais), are essential but are not problem-free. Given the lack of or delays in the distribution of food rations by the state, which are only provided to indigenous individuals living in villages, indigenous and nonindigenous organizations have mobilized in virtual environments to collect funds for the acquisition and distribution of basic food rations and personal hygiene products. The Socio-Environmental Institute (ISA) had counted 68 initiatives on its website till July 18, 2020 [18]. Access to emergency aid requires the recipients of these benefits to travel from villages to urban centers, potentially exposing them to the risk of infection in these environments. An evidence of the inadequacy of this measure in the indigenous context is the fact that traveling to the cities for this purpose ends up being mentioned in narratives that blame the indigenous peoples for the risk they are forced to take to access these benefits.

However, some remarkable advances have been made during this period, marked by indigenous mobilizations and confrontations against the federal government regarding their demands. These advances include actions by the Mixed Parliamentary Front for the Defense of Indigenous Peoples in the National Congress and the drafting of Bill 1142/20, which, among other aspects, provides for the guarantee of food security through various actions. In particular, the bill proposes the distribution of food, seeds, agricultural tools, and financial and technical support for production for the duration of the pandemic [19]. The formation of the front is in itself a milestone in the Brazilian political scene, bringing together members of various parties in the fight for indigenous rights in the National Congress, including the guarantee of the right to food.

Amid the rapid evolution of the pandemic in the indigenous environment and successive denunciations of the insufficiency of federal action, the bill, whose rapporteur was indigenous federal deputy Joênia Wapichana, was approved in the Chamber of Representatives and the Federal Senate. Within the scope of the executive powers, it was systematically vetoed, hindering actions considered fundamental for an effective fight against the pandemic [20]. At the time of drafting of this manuscript, the supporters of the bill were still mobilizing to increase the pressure for overriding the presidential vetoes in the Chamber of Representatives.

In parallel with these initiatives, the indigenous movement, through the Articulation of Indigenous Peoples of Brazil (APIB), with the support of several political parties, has filed a complaint of "Arguição de descumprimento de preceito fundamental" (non-compliance with a fundamental precept) before the Brazilian Superior Tribunal Federal (STF). The complaint was partially upheld by the STF, which determined, among other measures, the "devising and monitoring of a Covid-19 Coping Plan for the Brazilian Indigenous Peoples" and the participation of indigenous people in the process [21].

Indigenous peoples have played a fundamental role in these movements, which outline an unprecedented framework in the national political scene. They bring indigenous voices to the dialogue (and confrontation) with Brazilian society and politics. The debates on the situation of food insecurity among indigenous people, in their numerous expressions, are being held in this complex (and uncertain) political scenario, with profound implications for these peoples.

\section{CONCLUSION}

The indigenous peoples of Brazil are much more vulnerable to Covid-19 compared with the remaining Brazilian population, and this vulnerability has been socially and historically determined. The trajectory of the pandemic among the indigenous peoples has reaffirmed, if not deepened, the 
inequalities faced by them, with direct impacts on food security conditions. However, the necessary and urgent actions required to address this situation have been led by indigenous movements and collectives that have denounced the absent and slow official response as acts of institutional violence, which will have serious and lasting effects on the lives of these peoples.

\section{CONTRIBUTORS}

All authors contributed to the conception of the manuscript, analysis and interpretation of the data, and review and approval of the final version. The authors deny any conflicts of interest.

\section{RE FER E N CE S}

1. Fellows $M$, Paye V, Alencar $A$, Nicario M, Castro I, Coelho ME, et al. Não são números, são vidas! $A$ ameaça da Covid-19 aos povos indígenas da Amazônia. Projeto Amazônia Indígena e USAID. Amazonas: Instituto de Pesquisa Ambiental da Amazônia; 2020 [citado 18 jul 2020]. Disponível em: https://ipam.org.br/wp-content/ uploads/2020/06/NT-covid-indi\%CC\%81genas-amazo\%CC\%82nia.pdf

2. Codeço CT, Villela D, Coelho F, Bastos LS, Carvalho LM, Gomes MFC, et al. Risco de espalhamento da Covid-19 em populações indígenas: considerações preliminares sobre vulnerabilidade geográfica e sociodemográfica. Rio de Janeiro: Fiocruz; 2020 [citado 18 jul 2020]. Disponível em: https://portal.fiocruz.br/sites/portal. fiocruz.br/files/documentos/relatorios_tecnicos_-_covid-19_procc-emap-ensp-covid-19-report4_20200419indigenas.pdf

3. Centro de Pesquisas Epidemiológicas. Epicovid19-br divulga novos resultados sobre o Coronavírus no Brasil. Pelotas: Universidade Federal de Pelotas; 2020 [citado 18 jul 2020]. Disponível em: http://epidemio-ufpel. org.br/site/content/sala_imprensa/noticia_detalhe.php?noticia=3128

4. Articulação dos Povos Indígenas do Brasil. O crescimento do Covid-19 e a subnotificação de casos de óbitos na população indígena no Brasil. Brasília: Emergência Indígena; 2020 [citado 17 jul 2020]. Disponível em: http://emergenciaindigena.apib.info/o-crescimento-do-covid-19-e-a-subnotificacao-de-casos-de-obitos-napopulacao-indigena-no-brasil/

5. Coimbra CEA, Santos RV, Welch JR, Cardoso AM, Souza MC, Garnelo L, et al. The first national survey of indigenous people's health and nutrition in brazil: rationale, methodology, and overview of results. Bmc Public Health. 2013;13:52. https://doi.org/10.1186/1471-2458-13-52

6. Instituto Brasileiro de Geografia e Estatística. Censo demográfico 2010: características gerais dos indígenas. 2010. Rio de Janeiro: Instituto; 2010 [citado 17 jul 2020]. Disponível em: https://biblioteca.ibge.gov.br/ visualizacao/periodicos/95/cd_2010_indigenas_universo.pdf

7. Leite MS, Santos RVS, Coimbra JR, Álvares CE, Gugelmin SA. Alimentação e nutrição dos povos indígenas no Brasil. In: Kac G, Sichieri R, Gigante DP (organizadores). Epidemiologia Nutricional. Rio de Janeiro: Editora Fiocruz; 2007. https://doi.org/10.7476/9788575413203

8. Ragibaldoni N, Aquino JÁ, Madeira GP, Dal Fabbro AL. Prevalence of overweight and obesity in the adult indigenous population in Brazil: a systematic review with meta-analysis. Diabetes Metab Syndr. 2019;13;3. https://doi.org/10.1016/j.dsx.2019.03.024

9. Schmidt MI, Duncan BB, Silva GAE, Menezes AM, Monteiro CA, Barreto SM, et al. Chronic non-communicable diseases in Brazil: burden and current challenges. Lancet. 2011;377(9781):1949-61. https://doi.org/10.1016/ S0140-6736(11)60135-9

10. Welch JR, Ferreira AA, Souza MC, Coimbra Junior EA. food profiles of indigenous households in brazil: results of the first national survey of indigenous peoples' health and nutrition. Ecol Food Nutr. 2020 [cited 2020 July 18]. https://doi.org/10.1080/03670244.2020.1781105

11. Articulação dos Povos Indígenas do Brasil. Nota da APIB sobre os dados do aumento do desmatamento. Brasília: APIB; 2020 [citado 18 jun 2020]. Disponível em http://apib.info/2019/11/19/nota-da-apib-sobre-osdados-do-aumento-do-desmatamento-no-brasil/ 
12. Instituto de Estudos Socioeconômicos (Brasil). Ação da cidadania contra a fome, a miséria e pela vida. mapa da fome entre os povos indígenas no Brasil (II): contribuição à formulação de políticas de segurança alimentar sustentáveis. Brasília: Instituto; 1995.

13. Department of Economic and Social Affairs Indigenous Peoples. Covid-19 and indigenous peoples. New York: United Nations; 2020 [cited 2020 June 17]. Available from: https://www.un.org/development/desa/ indigenouspeoples/covid-19.html

14. Articulação dos Povos Indígenas do Brasil. Comunicado geral: acampamento terra livre adiado. Brasília: APIB; 2020 [citado 17 jun 2020]. Disponível em: http://apib.info/2020/03/12/comunicado-geral-acampamentoterra-livre-adiado/

15. Articulação dos Povos Indígenas do Brasil. Assembleia Nacional de Resistência Indígena. Brasil: 8 e 9 de maio de 2020. Brasília: APIB; 2020 [citado 15 jun 2020]. Disponível em: http://apib.info/2020/05/08/assista-aassembleia-da-resistencia-online/

16. Articulação dos Povos Indígenas do Brasil. Assembleia de resistência indígena: carta final. Brasília: APIB; 2020 [citado 17 julho 2020]. Disponível em http://apib.info/2020/05/10/carta-final-da-assembleia-deresiste\%cc\%82ncia-indigena/

17. Articulação dos Povos Indígenas do Brasil. Acampamento Terra Livre 2020: Documento final. Brasília: APIB; 2020 [citado 17 jul 2020]. Disponível em: http://apib.info/2020/05/01/acampamento-terra-livre-2020documento-final/

18. Instituto Socioambiental. Covid-19 e os povos indígenas: banco de iniciativas. São Paulo: Instituto; 2020 [citado 17 jun 2020]. Disponível em: https://covid19.socioambiental.org/banco-de-iniciativas

19. Brasil. Projeto de lei n. 1142, de 22 de maio de 2020. Dispõe sobre medidas de proteção social para prevenção do contágio e da disseminação da covid-19 nos territórios indígenas; cria o plano emergencial para enfrentamento à covid-19 nos territórios indígenas; estipula medidas de apoio às comunidades quilombolas e aos demais povos e comunidades tradicionais para o enfrentamento à covid-19; e altera a lei $n^{\circ} 8.080$, de 19 de setembro de 1990, a fim de assegurar aporte de recursos adicionais nas situações emergenciais e de calamidade pública. Brasília: Congresso Nacional; 2020 [citado 16 jun 2020]. Disponível em https://legis. senado.leg.br/sdleg-getter/documento?dm=8114589\&ts=1592335072269\&disposition=inline

20. Frente Parlamentar Mista em Defesa dos Direitos dos Povos Indígenas (Brasil). Pela vida dos povos indígenas, quilombolas, pescadores artesanais e demais povos e comunidades tradicionais. Carta aberta ao Congresso Nacional. Brasília: Abrasco; 2020 [citado 18 jul 2020] Disponível em: https://www.abrasco.org.br/site/ noticias/pela-vida-dos-povos-indigenas-quilombolas-pescadores-artesanais-e-demais-povos-e-comunidadestradicionais-carta-aberta-ao-congresso-nacional/50165/

21. Supremo Tribunal Federal (Brasil). Medida cautelar na arguição de descumprimento de preceito fundamental 709 Distrito Federal. Brasília: STF; 2020 [citado 17 jul 2020]. Disponível em: http://www.stf.jus.br/arquivo/ cms/noticianoticiastf/anexo/adpf709.pdf 